\title{
The Art(s) of Getting Lost: Halting Places for Culturally Responsive Research Methods
}

\author{
Eva Sæther
}

\begin{abstract}
This chapter revisits the ideas of radical empiricism and sensuous scholarship, embedded in current music education research. Focusing on the development of methodological implications of cultural responsiveness and arts-based research methods, the chapter argues for epistemic openness. The discussion is located within the author's own experiences of course development for Swedish music teacher students in Gambia, field studies in multicultural classrooms in Sweden, and research design that includes the fiddle, opening up for music to ask the questions. Borrowing from anthropological research the concepts of radical empiricism and sensuous scholarship, music education researchers might find useful tools to approach project planning, to perform the analysis of the material and to communicate the results in culturally responsive forms that inform both research and praxis. By studying music transmission with culturally sensitive research methods, this chapter suggests possibilities to do more than observing and reporting. There is a possibility to engage with different knowledge systems and politics, in all types of retrieved material - and to generate inclusive knowledge building.
\end{abstract}

Keywords Cultural sensitivity $\cdot$ Epistemology $\cdot$ Intercultural $\cdot$ Music education · Radical empiricism $\cdot$ Research methods $\cdot$ Sensuous scholarship

\section{Introduction}

... however, we will reach a destination where we will no longer have to write about writing ethnography, we will simply write our tales and sense that they are right. (Stoller 1987, p. 156).

\footnotetext{
E. Sæther $(\bowtie)$

Malmö Academy of Music, Lund University, Lund, Sweden

e-mail: eva.saether@mhm.lu.se
} 
Perhaps it all began that night in Abidjan, 1986. Against all good advice I was in Youpogoun, the district where all the Ivorians went for a good night of dancing. The open air "dance palaces," larger than football arenas, were crowded and beyond the fence wound a long line of those poor souls who could not afford the entrance ticket. This was where the best musicians played and the perfect place to be for a young, white music education student with research aspirations.

I had travelled as a participant observer of a group of Norwegian women who were learning African dance in Oslo at the Center for African Culture (CAK). Some of these white dancers had already been interviewed, in my gathering of material for a thesis on the drum as a tool for identity construction. Some of our co-travellers were Ivorian drummers, working in Norway as musicians for the Norwegian women's dance lessons. My interest was on the possible transformation of the values that the Ivorian drums carry in their original context, compared to the values the same drums come to carry both to the emigrated master drummers in exile, and the Norwegian women with an interest for the immigrants' culture.

There I was, dancing, against all good advice: "No you can't go there, yes, it is the place where we go, but it is not a place for you, you are white," said my friend the dance teacher. "No, you can't go," said the hotel receptionist. "Yes," his colleague said, "I will protect you." While my rescuer kept an eye on my soft drink and handbag, I was drawn into the circles of dancers, sweat dripping, and every now and then a paper banknote was put on my forehead.

The day after, these sweat pasted banknotes puzzled me. I know I am not a good dancer, so for sure they were not a proof of quality. To swipe away the sweat? To show the little value of money? I had to ask my friend. The answer is inscribed in my understanding of the emic and etic dimensions of practicing music education research with intercultural ambitions:

Didn't you understand that? The dance is everything to us? It carries everything in our culture, all of our lives. When you dance our dance, you show that you partly understand us, that you are part of us. That is why we put the banknotes on your forehead.

As years have gone by, these banknotes have kept haunting me. Through studies in musicology, music education, teaching at Malmö Academy of Music, developing courses, defending a thesis in music education, and continuing with research projects on intercultural approaches in music education, these banknotes tend to do their work as trouble makers: Who am I, as a White, ${ }^{1}$ privileged "homo academicus" (Bourdieu 1990), to "give voice" to "the other"? How might I use the episode of the banknotes to do more than unsettle my privileged position, to develop reflexive research methods that take into account the ethical imperatives of interculturality?

In this chapter, I revisit the ideas of radical empiricism (Jackson 1989), and sensuous scholarship (Stoller 1987, 1997), embedded in the development of current music education research. The methodological implications of cultural responsiveness (Kallio and Länsman 2018; Karlsen et al. 2016; Sæther 2015) form the

\footnotetext{
${ }^{1}$ Here, the term "White" is used with reference beyond phenotype. In this context "White" points to the embedded power relations that were at play during the field work.
} 
background to this effort to discuss how and why ethnographic work might be conducted, recognizing power dynamics, different ways of knowing, and more senses than the visual. As a background to the methodological considerations, I shortly introduce current trends in research on intercultural music education.

\section{Unstable Meanings}

Intercultural, as a concept, is elusive. Sometimes it appears in a "double-faced approach that reduces people to a (national) culture but at the same time claims that they have multiple and complex identities" (Risager and Dervin 2015, p. 3). In an effort to reach beyond essentialist thinking on culture, interculturality in this chapter is used as a concept that "foregrounds what could most inclusively be referred to as diversity and encounters" (Risager and Dervin 2015, p. 9) emphasizing the "inter," trying to avoid culturalism by a more "flexible, unstable and critical meaning" (ibid. p. 10).

In music education research, the concept intercultural appears in various contexts and combinations, for example, (i) in discussions on educational programs that enhance music teachers' intercultural competence (e.g., Hebert and Sæther 2014), (ii) on how institutions need to change in order to build structures that enhance intercultural learning and teaching (e.g., Miettinen et al. 2018; Schippers and Campbell 2012), or (iii) on critical reflections on the use of the concept (e.g., Kertz-Welzel 2018; Westerlund and Karlsen 2017). In her (2018) book Globalizing Music Education: A Framework, Kerz-Welzel argues for a culturally sensitive internationalization of music education, based on research from the field of intercultural education. Her vision of global music education rests on a critical (re)consideration of internationalization and constructs a framework for developing new ways of conceptualizing global music education. In this framework some of the components are educational transfer, global knowledge production, and a global mindset, where "international" is understood as intercultural encounters. Westerlund and Karlsen (2017) suggest that in order to avoid simplified and ethnocentric notions of interculturality, it is fruitful to focus on knowledge production. In doing so ". . . the acquisition of intercultural competences becomes a central concern" (p. 92) which helps avoid essentialist understandings of culture. In addition, with a strong focus on collaborative and interactive knowledge production “. . .co-developing intercultural music teacher education might provide one possible way to break the dominating, panoptical approach of diversity" (p. 100).

Schippers and Campbell (2012) are concerned that the implementation of intercultural music education is slow and present three possible reasons for this: (i) preconceptions and power structures in culturally diverse societies; (ii) static approaches to concepts such as authenticity, tradition, and context; and (iii) limited understanding of teacher-learner interaction across cultures. In an attempt to map possibilities and challenges for those involved in intercultural music education, Miettinen et al. (2018) asked music educators in Israel and Finland how they 
describe their own intercultural competence and how they look at important factors at the institutional level. The study reveals a lack of possibilities for music educators to learn from each other. It also pinpoints the importance of "subtle nuances brought out in and connected to specific localities, individuals and subject-related matters" (p. 83). In their discussion of the institutional level of intercultural music education, Hebert and Sæther (2014) argue for programs that provide music students with strong learning experiences outside their comfort zones. As the results from a study on the GLOMAS camp in Ghana show, the students were concerned about the quality of intercultural fusions. However, they strongly expressed the desire to "create something new" (p. 430) and the importance of respectful interaction.

\section{The Absence of Shortcuts}

The story line draws on Kirsten Hastrup's (1995) book A Passage to Anthropology: Between Experience and Theory where she, between experience and theory, writes herself back to Academia after a period of serious crises, where she had to question the validity and relevance of her own work. Each chapter in her book is a reflection on halting places, necessary for the continued journey. At each of these halting places, she unfolds experienced issues, such as context, symbolic violence, motivated bodies, unarticulated thoughts, the emic voice, and responsibility. There are, she argues, no shortcuts; the emic voice has to be heard, which implies responsibilities toward the "researched" as well as toward academic quality criteria. My interpretation of her work is that a cartography of research, following strict methodological formulae, is of no use. What is needed, in intercultural music education research and practice in particular, is the courage to get lost, in order to find new deterritorialized places for contemplation and reflection.

The art(s) of intentionally getting lost furthermore paves the way for the intuitive practitioner (Atkinson and Claxton 2003), the type of music education researcher and music teacher that current societal changes call for. In his expansion of Schön's (1991) reflective practitioner, Claxton (2003) explores dominant traditions of understanding the teacher profession, where rational, explicit, and articulated understanding is given priority over other knowledge forms. However, much of the work a teacher does happens in the moment, with the help of intuition. Not arguing for an anti-rational stance, Atkinson and Claxton (2003) show how the rational and the intuitive interact, together leading to development of professional practice. In my view, the questions posed addressing the teacher profession are also relevant to music education research: Can intuition be cultivated, and its quality improved? Is intuition a way of knowing that has "particular value in dealing with complexity?" (p. 3). In outlining the anatomy of intuition, Claxton (2003) highlights the non-mystical qualities of sensitivity, creativity, and rumination: "A balanced view of intuition is one which sees it as a valuable source of hypotheses, which are nonetheless capable of being interrogated" (p. 43). With references to a study on 
Nobel Prize winners' approach to intuition, the aesthetic and physical dimensions of learning and problem-solving are drawn into focus, as valid forms of knowing:

Professional development involves a shifting, dynamic interplay of different ways of knowing, and models of specific situations need to be developed which take into account their unique rhythms and 'melodies' of learning. (Claxton 2003, p. 46)

Thus, intentionally following the rhythms and melodies of emic voices and a plurality of knowledge forms, the following section takes a detour, halting at central theoretical and methodological concepts.

\subsection{Radical Empiricism and Writing Culture}

In retrospect, interrogating the banknote episode in Abidjan might serve as an accompaniment to a search for halting places for radical empiricism, sensuous scholarship, and cultural responsiveness in music education. The earlier mentioned "banknote on the sweat" incident was followed by a critical statement from the opponent at my public dissertation, musicologist Jan Ling. "There is no smell of Gambia in the text," he claimed. I was distressed. In my method chapter, I had clearly described how I used my own dancing as prompts before the interviews, to open up for a conversation on attitudes to musical learning in the Mandinka tradition. Furthermore, in the results chapter, I had pointed at the critical incident where the analysis took an unexpected turn - the questions were played by the ostinatos of the kora $^{2}$, thus guiding the interview conversation that took place on top of and in the music (Sæther 2015). However, as my opponent stated, the text of a dissertation is read as a text. Little did it matter that I had a CD attached to the book; it was still just an attachment.

During and after the fieldwork in Gambia, I had experienced the complications of giving the knowledge of Gambian master musicians a relevant and valid place in a Swedish PhD publication. Jackson's (1989) proposed concept of radical empiricism temporally served as a possible way forward. Expanding, or rather crumbling the notion of the participant observer as a researcher with ambitions to understand and represent the other by spending time together with the observed in rigorous fieldwork, radical empiricism focuses on experiences of the body. The concept asks researchers to rethink their scholarly being-in-the-world, in order to develop methods which do not violate or caricature the complexity, diversity, and ambiguity of culture and the human experience of culture. This is why I used my own dancing as an informal prelude to the more formal interviews, performed together with a musician, a jali.

A jali, in this case jali Alagi Mbye, is the "glue" of Mandinka society both historically and presently, the mediator between different power positions, the

\footnotetext{
${ }^{2} 21$-stringed West African harp lute.
} 
peacemaker in local conflicts, the expert in communication, and the one who sings and plays in a manner that penetrates and transforms the listener. With this long list of professional functions, it is not surprising that jali Alagi Mbye during the research project changed in relation to my function as researcher - from translator and travel guide to co-researcher. This transition is completely in line with the epistemological openness and the positioned narrator that radical empiricism entails. I, the positioned music education narrator and jali Alagi Mbye, the professional jali, found ourselves in the middle, being both/and rather than either/or.

When performing radical empiricism, the aspiration is not so much to narrate the truth; rather the interest lies in what truth effects the narration has (Jackson 1989). In the case of my PhD project, the effect can be described as twofold: (i) in my home, Academia, the dichotomy of formal-informal music education was questioned, and (ii) in jali Alagi Mbye's home, the Mandinka oral university, the conception of a wonderful and holy past was troubled. In these double truth effects lie traces of what Jackson (1989) describes as narration as shape-shifting and the narrator as shapeshifter. In a radical empiricist manner, we had dwelled in the middle, trying to resist typifications which hierarchize or demean human relations.

But the opponent still had a point, where was the smell, the groove, the music? There are conceptual and methodological implications of writing culture (Fortun 2009) constantly under development and in process. According to the anthropological understanding of the concept, culture can be understood as always under construction and in creation, something that is done in time and space, by inscription - a writing that is more than writing (Fortun 2009). Music education researchers, as other researchers, create culture by the very methods used in approaching, analyzing and writing about the research material. Therefore, we need to turn our attention toward how culture is written and the asymmetries between the observer and the observed. The problems of inscription are, for example, found within translation between different languages, formulation of field notes, and genres for ethnographic voices to have a conversation:

There is no formula. The right textual structure emerges from the material it structures. It draws readers into an intellectual labyrinth, laying out where they go without determining it, opening pathways for movement in different directions//. . //music might be the best way to translate alien forms into something with which imagined audiences can connect. (Fortun 2009, pp. xiii-xiv)

In analyzing inscriptions - for example, our own research reports - there are critical questions to be asked. Who is speaking? When and where? With who or to whom? In what institutional and historical constraints? What forms for inscription tend to structure our work and structure meaning? As Fortun (2009) states, we already know that our work is read within social webs. But, as she rhetorically asks, have we imagined how our work might help produce these webs? There are tasks waiting and conversations to take place provoked by books "and other performances" (Fortun 2009 , p. xiv). 


\section{Sensuous Scholarship and Partial Truths}

Understanding the "banknote on the sweat" as inscription, culture inscribed in dance, performed by using the sweat from my body to inform earlier inscriptions with other languages, it is worthwhile to dwell a little more with the banknotes. Was it pure serendipity that created this critical moment? Or was it my own cultural and bodily knowledge of what traditional folk music and dance might carry in terms of community building and expressive, emotional communication of important values? Of course, serendipity plays an important and welcomed role, but of equal importance is the blend of inscriptions that were at stake that night in Abidjan. As a researcher in the cross-disciplinary field of music education, my enculturation was inscribed with the help of ethnomusicological theories and methodologies, thinking not of music and culture but of music as culture.

Within music education research, questions about transmission of knowledge (learning) are in focus. What musical styles are considered important enough to study within higher music education? What kinds of teaching are promoted, studentcentered, group-based, or one-to-one methods? As Nettl (1995) stated, the answers to questions like these point toward the realization that it is in the teaching methods the core values of cultures become visible: "teaching methods, musical events, and institutions particularly involved in teaching - must be the ones in which the aspects of culture that music teaches are most characteristically found"(Nettl 1995, p. 70). His fieldwork results from studying music education at home (in America) raised concerns about a monocultural, hegemonic school music practice, based on Western art music teaching and performance traditions. In Sweden, the hegemony of Western art music in music education in schools was broken in the late 1980s and early 1990s as a result of a national reform (Olsson 1993) demanding a wider pallet of genres within higher music education. However, the teaching methods and the ways of conceptualizing music still remained based on the Conservatory tradition, which was one of the reasons for my study in Gambia - searching for other attitudes to music and musicality that would make sense in widening participation at home.

Struggling with the fact that my thesis did not smell like the red earth of Gambia, I turned to Paul Stoller, the American anthropologist who in his early career travelled to Niger to study language use. His initial and very serious intent was to inquire into how and when different coexisting local languages were used in different social contexts, such as political decision-making or household issues. He failed completely. Prepared with a research design that included, for example, a quantitative survey (in a village where reading was not a common skill) and with very vague ideas about the concept of time in an orally transmitted culture, he quickly reached a point of despair. Running out of funds, realizing that the villagers had deliberately not provided him with the answers he was hunting for, he finally sat down with one of the elders in the village. The advice was to learn how to listen and "how to smell the world," that is, to engage with the ontology of the culture he had planned to study: "Listen to the godji (violin) and let its cries penetrate you. Then you will know 
the voice of the spirits, they would tell me. Feel the sound of the drum and know the power of our past" (Stoller 1989, p. 101).

Consequently, the embarrassed early career researcher with an interest in linguistics stayed 10 years in Niger and learned how "to smell the world." On his return he wrote In Sorcery's Shadow (1987) and Sensuous Scholarship (1997), both books reminding us about the importance of including an open attitude toward epistemology and ontology - in teaching as well as in research. In later works, Stoller (2004) shows how a sensuous description "propels social scientists to reconsider the analysis of power-in-the-world" (p. 820), in improved clarity and force of the ethnographic work. Stoller (2004) offers the practice of sensuous scholarship as much more than an epistemological practice belonging to isolated researchers. It is an answer to wider questions of scholarly responsibilities and the purpose of social science: ". . many contemporary scholars have lost their way in the academic maze" (p. 832). By sensuous work, there is a potential to "shock readers into newfound awareness...to think new thoughts" (p. 283) and contribute to research on the human condition. For the field of music education, our being-in-the-world with music might already have influenced our ways of performing research; however, there might be more to it, following the line of thought within sensuous scholarship. In this line, the poetic and the political are intertwined, and ethnography as an art situated between different systems of meaning (Clifford 2009). "Ethnography decodes and recodes, telling the grounds of collective order and diversity, inclusion and exclusion. It describes processes of innovation and structuration and is itself part of these processes" (Clifford 2009, pp. 2-3). Therefore, all ethnographic texts cannot be more than "partial truths" (Clifford 2009, p. 7), as power and history work through the researcher. Still, ethnographic work, in exploring the limitations of representation, is potentially counter-hegemonic. Writing, within the realm of sensuous scholarship, includes power, institutional resistance, and innovation. Thus, as a PhD student, the intuitive decision to include a CD-recording of the kora asking the questions had to compromise with the standard format of writing up a thesis. Now, 13 years later there are other solutions available, allowing both for acknowledged co-researching and modes for presenting results that at least partially reduce the problem with "partial truths" by including for example sound files, videos, and poetry in the research report.

\section{Cultural Responsiveness}

The dilemmas for music education researchers involved in cross-cultural and intercultural projects like developing music education in majority world countries, with reference to Western epistemological approaches toward learning, are plenty. Striving with different forms of co-working, Treacy et al. (2019) and Westerlund and Karlsen (2017) in their results highlight the learning process that lies in working outside of the learners' comfort zones, realizing the need for developing culturally responsive research methods. 
In a meta-analysis of projects carried out within the Sibelius Academy, based on a review of international intercultural pedagogic practice (Karlsen et al. 2016), some of the major ethical considerations related to intercultural research and practice emerge:

- There is often a danger of exploitation and colonialism.

- There is often a troubling question of whose voice is represented in research.

- There are often emotional challenges involved intercultural learning.

- There might be language barriers that limit the possibilities of mutual understanding.

- There might be institutional power issues involved.

- There might be overlooked political aspects of research.

- It might be complicated to safeguard the integrity of participants.

The responsibility for developing the professional competence needed to engage with lists such as the seven ethical considerations lies largely within institutions for higher music education and their capacity to reach out for partnerships that stir academic cultures. The Global Visions projects' activities is one example of such ongoing initiatives. Based on the Manamaiju total immersion musical workshop in Nepal March 2017, the deeply involved masters and PhD students report on inspiring, yet challenging, learning experiences from making music together with master musicians in a village recovering after the 2015 earthquake (Johnson 2018). Through musicianship practiced as an integrated form for knowing, creating, developing, and performing, the non-Nepali participants were invited to reconsider both educational and research-related issues, including culturally responsive approaches. For the Nepali participants, the collaborative musical workshops opened up spaces for negotiating the global and the local, in ways that minimized Othering. Notwithstanding, there is reason to be aware of long-lasting power structures and long-lived colonial discourses. In discussing the pedagogical outcomes of the Manamaiju musical meetings, Upadhayaya (2018) is concerned about the potentially naïve expectations of confluence:

\footnotetext{
In order to tackle all the complexities and challenges (the socio-cultural, the socio-political, the socio-economic, and the socio-religious) that can surface during the process of intercultural or cross-cultural amalgamation and learning the variety of discourses that exist in music, critical research to ensure unbiased interpretation, negotiation, and production is called for. To do so, I would suggest that rather than aiming at overnight cultural confluence which would in fact be a waste of time, money and energy, all the stakeholders in this process should try to primarily understand the power dynamics rather than trying to diffuse them, to ensure a safe house for an envisaged confluence in globalized, social and virtual spaces. (pp. 98-99)
}

There is no quick fix. In Finland, as in the Nordic countries in general, there is a majority belief that the national policies on inclusion and democracy ensure the rights of minorities. However, there are reasons to go beyond this safe zone of official declarations. The problems of "partial truths" and power dynamics require 
thorough methodological work. Through "joik ${ }^{3}$-research," Kallio and Länsman (2018) managed to collaboratively create the composite character of Áile through an "indigenized analysis approach" (p. 9) where Áile's voice is "the polyphonic tapestry of many" (p. 9). Through collaborative narrative analysis, the voice of Áile was crafted as a joik, a powerful inscription.

Together, the researchers decided to penetrate the role of joik in communication and meaning construction. Their joint and engaged work with creating the character of Áile enabled a visionary discussion on future directions for Nordic extracurricular arts education, based on the Sami gift philosophy Attaldát that acknowledges interconnectedness. The "joik-research" performed by Kallio and Länsman (2018) is described as sometimes pushing the researchers into an area of discomfort. This is not to be interpreted as a problem; rather it is a method to include "those who understand and/or experience the world differently. Thus, significant learning ethical learning - requires an element of discomfort" (p. 16). Cultural responsiveness in this discomforting quality thereby enhances community inclusion in issues of validity and reliability.

\section{Concluding Discussion}

Following the line of thought from sensuous scholarship and radical empiricism, there is a need to analyze how music education research texts function as inscriptions, that is, texts that are more than texts and texts that are created by culture and creating culture, including more senses than the visual. Understanding texts as inscriptions invites texts that allow for other ways of knowing, for example, intuitive experience. As Fortun (2009) suggests, "music might be the best way" (p. xiv) to reach new audiences and to produce knowledge with the help of culturally responsive methods. Nevertheless, institutional and historical limitations always guide researchers' work, as the researchers' analyses are "always enmeshed in global movements of difference and power" (Clifford 2009, p. 25).

Emerging collaborative research formats, such as "joik-research" of Kallio and Länsman (2018), show how academic culture might be renewed in the in between of different subjects in different power relations. The growing body of results from the ongoing Global Visions project further adds to the picture of how music and music education have a capacity to contribute to knowledge on diversity and culturally responsive research methods.

With roots in the troubling banknotes from early fieldwork in Ivory Coast, the efforts to develop a research profile on intercultural perspectives on musical learning at the Malmö Academy of Music have focused on "borderland" educators and "borderland" researchers (Sæther 2015), didactic and epistemological awakenings,

\footnotetext{
${ }^{3}$ The Sámi vocal tradition of Joik is not a song, or a way of singing per se, but "a means to establish solidarity and position oneself and others in Sami communities" (Kallio and Länsman 2018, p. 9).
} 
and intercultural pedagogic competence (Lorentz 2016) all very "uncomfortable" positions and activities. Getting lost, or rather the art(s) of getting lost as the title of this chapter suggests, is an effort to invite both intuition and discomfort. They are invited as ingredients in music education research, as parts of theoretical frameworks that might frame and advance contemporary understandings of diversity in music education.

By borrowing from anthropological research the concepts of radical empiricism and sensuous scholarship, music education researchers might find useful tools to approach project planning, to analyze the material and to write about/publish the results in culturally responsive forms that inform both research and praxis. Music, and music education, has a potential to contribute to knowledge inclusion. There is a close relation between research and teaching methods since, as Nettl (1995) suggests, it is in the teaching methods and teaching institutions that we will find the core values of a culture. It is therefore, by studying music transmission with culturally sensitive research methods, possible to do more than observing and reporting.

Finally, inscriptions that include the music, the body, the sweat, inspired by sensuous scholarship and radical empiricism, still need to be rigorous. Clifford (2009) writes about ethnographic work as poetry, a form of poetry that is precise. Likewise, music education researchers have the possibility to regard inscription as creating culture - in music and with music. There is a possibility to engage with different knowledge systems and politics, in all types of retrieved material. And there is a possibility to imagine research as creative, collaborative deliberations, generating social and cultural forms for knowledge building.

\section{References}

Atkinson, T., \& Claxton, G. (Eds.). (2003). The intuitive practitioner. On the value of not always knowing what one is doing. Maidenhead: Open University Press, McGraw-Hill Education.

Bourdieu, P. (1990). Homo academicus. Stanford: Stanford University Press.

Claxton, G. (2003). The anatomy of intuition. In T. Atkinson \& G. Glaxton (Eds.), On the value of not always knowing what one is doing (pp. 32-52). Maidenhead: Open University Press, McGraw-Hill Education.

Clifford, J. (2009). Introduction: Partial truths. In J. Clifford \& G. E. Marcus (Eds.), Writing culture: The poetics and politics of ethnography (2nd ed., pp. 1-26). Berkeley and Los Angeles: University of California Press.

Fortun, K. (2009). Of writing culture, 2020. In J. Clifford \& G. E. Marcus (Eds.), Writing culture: The poetics and politics of ethnography (2nd ed., pp. vii-xxii). Berkeley and Los Angeles: University of California Press.

Hastrup, K. (1995). A passage to anthropology: Between experience and theory. London: Routledge.

Hebert, D., \& Sæther, E. (2014). "Please, give me space": Findings and implications of the GLOMUS intercultural music camp, Ghana 2011. Music Education Research, 16(4), 418-435.

Jackson, M. (1989). Paths towards a clearing: Radical empiricism and ethnographic inquiry. Bloomington: Indiana University Press. 
Johnson, D. (Ed.). (2018). Confluence - perspectives from an intercultural music exchange in Nepal (perspectives in music and music education, 12). Malmö. Malmö Academy of Music: Lund University.

Kallio, A. A., \& Länsman, H. (2018). Sami re-imaginings of equality in/through extracurricular arts education in Finland. International Journal of Education \& the Arts, 19(7). https://doi.org/10. 18113/P8ijea1907. Accessed 18 June 2020.

Karlsen, S., Westerlund, H., \& Miettinen, L. (2016). Intercultural practice as research in higher music education: The imperative of an ethics-based rationale. In P. Burnard, E. Mackinlay, \& K. Powell (Eds.), The Routledge international handbook of intercultural arts research (pp. 369-379). New York: Routledge.

Kertz-Welzel, A. (2018). Globalizing music education: A framework. Bloomington: Indiana University Press.

Lorentz, H. (2016). Interkulturell pedagogisk kompetens. Transformativ akademisk kunskap om integration i dagens skola. [Intercultural pedagogic competence. Transformative academic knowledge on integration in the school.]. In H. Lorentz \& B. Bergstedt (Eds.), Interkulturella perspektiv. Pedagogik i mångkulturella lärandemiljöer [Intercultural perspectives. Pedagogy in multicultural learning contexts] (pp. 161-188). Lund: Studentlitteratur.

Miettinen, L., Gluschankof, C., Karlsen, S., \& Westerlund, H. (2018). Initiating mobilizing networks: Mapping intercultural competences in two music teacher programmes in Israel and Finland. Research Studies in Music Education, 40(1), 67-88.

Nettl, B. (1995). Heartland excursions: Ethnomusicological reflections of schools of music (music in American life). Urbana and Chicago: University of Illinois Press.

Olsson, B. (1993). SÄMUS en musikutbildning $i$ kulturpolitikens tjänst? En studie om musikutbildning på 1970-talet [SÄMUS - music education in the service of a cultural policy? A study of a teacher training programme during the 1970s] (Vol. 33). Göteborg: Musikhögskolan.

Risager, K., \& Dervin, F. (2015). Introduction. In F. Dervin \& K. Risager (Eds.), Researching identity and interculturality (pp. 1-25). LondonlNew York: Routledge.

Sæther, E. (2015). Exploring musical research sensibilities. In L. Bresler (Ed.), Beyond methods: Lessons from the arts to qualitative research (pp. 97-111). Malmö: Malmö Academy of Music.

Schippers, H., \& Campbell, P. (2012). Cultural diversity: Beyond "songs from every land". In G. E. McPherson \& G. F. Welch (Eds.), The Oxford handbook of music education (Vol. 1). Oxford: Oxford University Press. https://doi.org/10.1093/oxfordhb/9780199730810.013.0006.

Schön, D. (1991). The reflective practitioner. How professionals think in action. Farnham: Ashgate Publishing Limited.

Stoller, P. (1987). In sorcery's shadow. A memoir of apprenticeship among the Songhay of Niger. Chicago: University of Chicago Press.

Stoller, P. (1989). The taste of ethnographic things: The senses in anthropology. Philadelphia: University of Pennsylvania Press.

Stoller, P. (1997). Sensuous scholarship. Philadelphia: University of Pennsylvania Press.

Stoller, P. (2004). Sensuous ethnography, African persuasions, and social knowledge. Qualitative Inquiry, 10(6), 817-835. https://doi.org/10.1177/1077800404265727.

Treacy, D., Timonen, V., Kallio, A., \& Shah, I. B. (2019). Imagining ends-not-yet-in-view: The ethics of assessment as valuation in Nepali music education. In D. J. Elliott, M. Silverman, \& G. E. McPherson (Eds.), The Oxford handbook of philosophical and qualitative assessment in music education (pp. 411-429). New York: Oxford University Press. https://doi.org/10.1093/ oxfordhb/9780190265182.013.33.

Upadhayaya, P. K. (2018). Negotiating the global and the local: The fragile location of south Asian discourses in the globalized cosmopolitan context. In D. Johnson (Ed.), Confluence - perspectives from an intercultural exchange in Nepal (pp. 93-100). Malmö: Malmö Academy of Music, Lund University.

Westerlund, H., \& Karlsen, S. (2017). Knowledge production beyond local and national blindspots: Remedying professional ocularcentrism of diversity in music teacher education. Action, Criticism, and Theory for Music Education, 16(3), 78-107. 
Eva Sæther is professor in music education at Lund University, Malmö Academy of Music (MAM), and docent at University of the Arts, Helsinki. She has developed a research profile that focuses on intercultural perspectives on musical learning and creativity(ies). She teaches educational sciences at the music teacher education program, and since 2017 she is heading the research education in music education at MAM. From 2017 to 2020 she serveds as a board member of the International Society for Music Education (ISME).

Open Access This chapter is licensed under the terms of the Creative Commons Attribution 4.0 International License (http://creativecommons.org/licenses/by/4.0/), which permits use, sharing, adaptation, distribution and reproduction in any medium or format, as long as you give appropriate credit to the original author(s) and the source, provide a link to the Creative Commons license and indicate if changes were made.

The images or other third party material in this chapter are included in the chapter's Creative Commons license, unless indicated otherwise in a credit line to the material. If material is not included in the chapter's Creative Commons license and your intended use is not permitted by statutory regulation or exceeds the permitted use, you will need to obtain permission directly from the copyright holder.

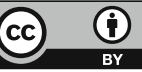

